\section{Goodbye Malthus, hello humankind}

Everybody knows about the African drylands: blasted, burned by drought and trashed by hordes of pastoralists and feckless farmers. Malthus was right: in the Sahel there are too many people and too many livestock. Systems of land management are adapted to moving on, fallowing land and seeking new pastures. As populations have grown people have run out of space, their agriculture strips nutrients out of the soil and their animals defoliate the range. Eventually the soil itself blows away, leaving desert behind.

This is all familiar enough. We often call on images of dryland degradation when we want to make a general point that people threaten wildlife. We learned this story in the 1970s, when the 'Sahel drought' first impinged on Northern consciousness, and grew more sure of the story through the dry decades of the rest of the century. But is it true? Increasingly, research is suggesting that the real story of environmental and economic change in the African drylands is much more complicated.

First, the automatic assumption that pastoralists overgraze rangelands and cause permanent degradation has been challenged by research on indigenous pastoral management. Rainfall is now recognised as the external driver of rangeland productivity. Pastoralists track that productivity in space and time. A wide range of formal and informal institutions govern pastoral management; their links with both economy and culture are complex. It was widely assumed in the 1970s that overgrazing could intensify drought, through bio-geophysical feedback (e.g. by increasing land surface albedo through destruction of vegetation), but climatologists now model variations in African dryland rainfall primarily as a product of sea surface temperature anomalies and ENSO cycles. Pastoral lands are often degraded, but the process is not uniform in space and the causes are far from simple. Malthus is a poor guide to the problem.

Second, research in Africa in the 1990s has questioned the inevitability of the link between rural population growth and environmental degradation. The now classic study is of Machakos District in Kenya, in the provocatively titled book More People, Less Erosion (Tiffen et al., 1994). In the 1930s Machakos was highlighted as an example of soil erosion under relentless pressure of population. Like the rest of Kenya, its population has subsequently surged, from 240,000 people in 1930 to 1.4 million in 1990. However, not only has Malthusian disaster been averted, but the total value of agricultural output rose 11 times and the per capita value three times between 1930 and 1990, as farmers invested offfarm incomes in land, intensified production, turned to cash crops like coffee, harnessed labour to terrace hillsides, and made use of denser networks of contacts to learn new ideas and sell their produce.

Machakos is not unique. In northern Nigeria, high rural population densities have been maintained for centuries in the close-settled zone around Kano City. Land is an intensively managed 'farmed parkland', with closely-packed fields set with economic trees. Fallow land has been steadily swallowed up. By 1991 only 13\% of land was uncultivated, and rural population densities were 348 people per square kilometre. Yet there has been no eco-disaster, and tree densities have been maintained. In this 'farmed parkland' landscape, agriculture is diverse, with a wide range of local varieties of crops grown together in different relay cropping mixtures (Mortimore, 1998). Soil fertility is maintained through the close management of nutrient cycles, use of legume crops and the integration of agriculture and livestock keeping. Drier areas further from Kano City appear now to be undergoing the same transition, from low-density lowinput agriculture to high-density high-input agriculture (Mortimore, 1998).

Comparable findings to these have been reported from elsewhere, such as Senegal and Niger. This research is having a significant impact on the way development policy-makers think about African agriculture. Outside observers in the 1970s portrayed dryland farmers as poised on the cusp of Malthusian disaster. Three decades later, vastly increased populations have been absorbed by rural production systems. This is not the work of clever 'green revolution' scientists, fertiliser manufacturers or aid donors, let alone inspired national governments. This is the work of human hands, steadily applied to the task of survival. Things are tough for dryland farmers, and poverty is a killing problem. But so far they have avoided the Malthusian disaster predicted for them. We need to understand how they are doing it.

So what, I hear you say? What if some social scientists are getting excited about African farmlands and trying to change the way we think about drought and poverty? What has this got to do with conservation of biodiversity? After all, there is very little wildlife left in the West 
African drylands, and the area lies far from the 'hotspots' of lowland forest, montane forest or fynbos. Well, I think there are several things here that are important for conservationists, and not only those interested in Africa.

First, our ideas about desertification matter. They run deep within our ideas about the way people use rural environments in the Third World. Implicitly we accept that what goes for the Sahel goes for other landscapes also: poor rural people degrade their environment. But if people are managing to sustain their agriculture while rural populations rise, maybe we should think again about the inevitability of Malthusian disaster. Maybe the Third World rural poor are working to a different script. Maybe our generalisations about the evils of population growth among the rural poor need reconsideration.

Second, even farmed African drylands also matter for conservation in a more conventional way. Since the Sahel drought of 1974, it has been known that trees and shrubs in the Sahel are important for migratory warblers such as the Whitethroat Sylvia communis. The management of fields and pastures, and of woody vegetation within the landscape, are highly important for the Palaearctic-African migration system (Stoate et al., 2001). The ways people micro-manage African drylands (and even more importantly wetlands) has global conservation importance. Our enthusiasm for biodiversity hotspots and protected areas should not blind us to the conservation importance of more mundane landscapes.

Third, farmed African drylands highlight a real challenge for African conservation, which is the need for a secure social foundation. Conservation in Europe and North America is empowered by a broad social movement. In Africa it is powered by international (largely European and American) ideas promoted by a tiny national minority in turn driven by aid donors and NGOs. Ultimately, apart from a few foreign-owned reserves, what gets conserved in Africa will be what ordinary Africans themselves think is important, and are willing, and able, to pay for. People may come to want the national parks we outsiders have persuaded their governments to set aside, and acquire the wealth to pay for them. However, for most of us a concern for nature comes first from wildlife closer to home. Who is speaking for the ordinary wildlife of Africa? Who is conserving the biodiversity that may persuade Africa's ordinary people that conservation is important for them?

There is biodiversity in Third World farmlands too, even if it is not the kind we usually get professionally excited about. In the creation of Africa's intensively managed farm landscapes, biodiversity is both lost and created. You don't see much wildlife in the Sahel, but it is there: more beetles than bulldozer herbivores, but it's real enough. Over a long history, people have industriously converted natural ecosystems in ways that raise economic productivity and provide livelihoods. The same economic forces are at work as in temperate farmlands, and here too wildlife ends up in the cracks left by human enterprise. Can we enhance the biodiversity of these farmed landscapes? I don't think we have thought much about that yet. How much biodiversity is there, in Africa's farmlands and rangelands, outside hotspots and national parks? Apart possibly from birds, I wonder if we have looked very hard to find out.

On my journey to work in Cambridge, I pass a field where a new hedge is being planted. I don't know if it is the farmer's philanthropy or a well-targeted government conservation grant that is putting a line of hawthorn back around this bleak arable field. But this is typical of conservation in the UK, painstakingly replacing the building blocks of biodiversity in a farmed landscape. Should we not have similar care for the ordinary landscapes of Africa? Should we not have a real interest in the livelihoods of the poor, and the kinds of landscapes they create?

W.M. Adams

Department of Geography

University of Cambridge, CB2 3EN, UK

\section{References}

Mortimore, M. (1998) Roots in the African Dust: Sustaining the Drylands. Cambridge University Press, Cambridge, UK.

Stoate, C., Morris, R.M. \& Wilson, J.D. (2001) Cultural ecology of Whitethroat (Sylvia communis) habitat management by farmers: winter farmland trees and shrubs in Senegal. Journal of Environmental Management, 62, 343-356.

Tiffen, M., Mortimore, M.J. \& Gichugi, F. (1994) More People, Less Erosion: Environmental Recovery in Kenya. Wiley, Chichester, UK. 